\title{
BEAUTY AND THE BEAST: MISREPRESENTATION AND SOCIAL RESPONSES IN FAIRY-TALE ROMANCE AND REDEMPTION
}

\author{
Linda Coates, Shelly Bonnah, and Cathy Richardson
}

\begin{abstract}
Violence perpetrated in romantic or intimate relationships is common, dangerous, chronic, and gendered: males tend to commit this violence against females. We critically analyze scenes from the beginning of the 1991 film Beauty and the Beast using the theory of response-based practice to show how the film uses misrepresentation and social responses to disappear violence and advance the narrative of a fairy-tale love story. In response-based practice, the actions of social responders - people who respond to victims and perpetrators - are recognized as important for understanding the actions of the victims and perpetrators themselves. In this film, the servants are social responders and their actions are critical to the narrative of the film. We show how the servants actively use mutualization and misrepresentation to reformulate events, conceal the Beast's abusive or violent actions, and obfuscate his responsibility for those actions: the Beast is held responsible merely for being uncouth in difficult circumstances. Each misrepresentation and each social response join together to create a story that is understandable as romance and redemption. In doing so, the tale can be understood as supporting many myths about violence against women and girls in intimate relationships. The film produces and reproduces common misrepresentations of violent social interaction, perpetrator actions, victim resistance, and the violence itself.
\end{abstract}

Keywords: response-based practice, feminine socialization, social responses, resistance to violence, violence

Linda Coates $\mathrm{PhD}$ (corresponding author) is an Associate Professor at Okanagan College, Department of Psychology in Salmon Arm, $255210^{\text {th }}$ Avenue N.E., Salmon Arm, BC VIE 2S4. Email: lindaresponds@gmail.com

Shelly Bonnah $\mathrm{PhD}$ is an associate faculty member at City University of Seattle, 677 Seymour St., Kamloops, BC V2C 2H1. Email: sbonnah@rbpinterior.com

Cathy Richardson/Kinewesquao $\mathrm{PhD}$ is an Associate Professor in Social Work at the University of Montreal, Pavillon Lionel Groulx, 3150 rue Jean Brillant, Montreal, QC H3T 1N8. Email: catherine.richardson@umontreal.ca 
Violence in intimate relationships is a serious problem: it is too frequent, too dangerous, and too chronic. This form of violence is gendered: typically, it involves men exerting coercive control over or violating women and children (Perreault. 2015; WHO, 2017). It has also become clear that this form of violence is not limited to adult relationships. People report violence in dating relationships as early as grade school. While both girls and boys report physical, psychological, and sexualized ${ }^{1}$ victimization in relationships, the victimization rates are substantially higher for girls (see Centers for Disease Control and Prevention, 2015; DeKeseredy \& Kelly, 1993; Kelley, 2006).

There is also a connection between adolescent victimization and suffering future assaults. Being physically assaulted as a young person is correlated with being raped, physically violated, or stalked by an intimate partner as an adult (Turpel-Lafond, 2012). Moreover, problems in adolescent romantic relationships are connected to suicide risk: a review of the 89 suicide and selfharm cases of youth in government care in British Columbia revealed that "approximately onethird of the youth had a romantic conflict in the 24 hours preceding their suicide or self-injury" (Turpel-Lafond, 2012, p. 5) This study did not define "conflict" but on the basis of our research, consulting, and clinical experience it is likely that the mutualizing term (Coates, 1997) also includes actions that fit the definition of family violence such as coercive control and assault.

Given the importance of romantic or intimate relationships and the pervasiveness of violence in these relationships, it is fitting that we critically analyse what we have taught children, adolescents, young adults, and adults about romantic or loving relationships. To that end, in this paper, we briefly analyse some of the early scenes from the 1991 movie version of Beauty and the Beast from a response-based practice perspective (Coates \& Wade, 2007, Richardson, 2008; Richardson \& Bonnah, 2015). In particular, we will show how misrepresentation and social responses are used to reformulate violence and create a love story in the film.

\section{In-Dignity: Response-Based Practice}

Response-based practice is a social science theory that was developed from research and clinical practice. The theory emphasizes contextual analysis of social interaction to gain understanding of people and their actions (Coates \& Wade, 2004, 2007). One of the areas we have focused upon in our clinical and consulting practices is interpersonal violence, including intimate partner violence. We work with a wide range of clients, including victims, perpetrators, adults, and children who come from diverse cultural, economic, and gender identity positions. We incorporate into our practice research, training, document analysis, therapy, assessments, and investigations. A comprehensive explanation of our theory is beyond the scope of this paper, but Table 1 lists

\footnotetext{
${ }^{1}$ In the 1980 s Coates began using the term "sexualized" violence rather than "sexual" violence because "sexual" is a mutualizing term. Violent social interactions are unilateral, not mutual.
} 
some of the tenets of response-based practice that are most relevant to this analysis, which will focus on social responses and representation.

Table 1 Selected Tenets of In-Dignity or Response-Based Practice

\begin{tabular}{ll}
\hline Term & \multicolumn{1}{c}{ Tenet } \\
\hline Social interaction & $\begin{array}{l}\text { Violence occurs when a perpetrator applies force against a victim within a particular } \\
\text { social interaction. } \\
\text { Tnteractants }\end{array}$ \\
Resistance & When violent interaction is examined, we see that victim resistance is ever-present. \\
& Whenever people are mistreated, they resist. \\
Contextual analysis & $\begin{array}{l}\text { Meaning is contextual. Consequently, social interaction, including violence, must be } \\
\text { examined within its context. }\end{array}$ \\
Micro and macro & $\begin{array}{l}\text { Relevant context includes both micro and macro details of the person's situation and } \\
\text { social world. }\end{array}$ \\
Social responses & How other people respond is important to both perpetrators and victims. \\
& Both perpetrators and victims take into account actual and anticipated social responses. \\
& Representation is a potent social response. \\
& Violence is frequently misrepresented as mutual; that is, as a joint action of the \\
& perpetrator and the victim.
\end{tabular}

Note. Adapted from Coates \& Wade (2007).

When people are mistreated, especially when a person has been victimized through violence, how other people respond, or are anticipated to respond, is a vital concern. The quality of actual and anticipated social responses influences what perpetrators, victims, and others do, say to others, and think. The term "social responses" refers to the actual and anticipated responses of other people to victims and perpetrators of violence, abuse, and other forms of adversity (Richardson \& Wade, 2008). The range of social responders is immense and includes, but is not limited to:

- members of social networks (e.g., family, friends, neighbours, workmates),

- members of social institutions (e.g., child protection services, police services, prosecution services, medical services, therapeutic services, advocacy services, educational services, administration and support services),

- members of the media and entertainment industry (e.g., novelists, screenplay writers, journalists),

- individuals present during violence (e.g., bystanders, interveners, witnesses), and

- individuals who gain knowledge of perpetration or victimization (e.g., classmates, friends, general public). 
Social responders are integral to affirming that the violence was wrong, that the victim was not responsible, that the victim is worthy of social concern and redress, and upholding the social meaning of the actions. Through social responses, others may provide victims comfort and safety, reassert victim dignity, uphold the violence as wrongful, and aid in the management of offenders. How individuals act in relation to both the victim and offender can ensure that institutional responses are fair, just, and effective.

Given the important functions of social responses, it is not surprising that both victims and perpetrators take into account actual and anticipated social responses in forming their "situational logic" (de Certeau, 1984). To understand, for example, why victims of sexual assault and harassment did not publicly speak out until the "me too" movement, one needs to understand offender actions and social responses. When victims anticipate or know from experience that perpetrators can prevent them from getting jobs, that authorities will refuse to fully investigate, that judges will acquit no matter the quality of the evidence, and that journalists will hurt rather than help, victims are far less likely to come forward. When the social responses to victims publicly began to change, more and more victims of sexualized violence came forward to describe the violence perpetrated against them ${ }^{2}$. How other victims respond is directly connected to the quality of the social responses received by those coming forward.

One important social response is the act of representing violence. Giving meaning by fitting words to deeds, music to situations, images to scenes, and so on is an inherently political practice. Offering or giving meaning to events inevitably characterizes victims and offenders, characterizes the nature of the social interaction, attributes cause, and connects the events in question to other events (Fowler, Hodge, Kress, \& Trew, 1979). In particular, professionals, including screenplay writers, put forth written, verbal, auditory, and visual representations as a routine part of their practice. These representations can have profound consequences for victims of violence.

Coates first recognized the importance of social responses to violence in the 1980s when she was researching legal responses to sexualized assault. Coates and colleagues found then as now that misrepresentations of violence are ubiquitous in media (e.g., novels, films, articles), legal documents, therapy sessions, school responses, and more (see Coates, 1996; Coates, 1997; Coates \& Wade, 2007, 2012). We have found in our research, consulting, and clinical practice that interventions are more likely to be consistent with false representations of the violence than with the accurate details of the violence itself. For example, sexualized violence, spousal assault, and other forms of violence are frequently misrepresented as mutual, not unilateral, acts of violence (see Coates, 1996; Coates, 1997; Coates \& Wade, 2007). Such false representations have important

\footnotetext{
${ }^{2}$ We would like to recognize journalist Ronan Farrow for providing a positive social response to victims of violence by exposing sexualized violence. We note with interest that Farrow's experiences in his family may be directly connected with his refusal to be silenced.
} 
International Journal of Child, Youth and Family Studies (2019) 10(1): 119-136

consequences for victims of violence. Thus, how we represent or misrepresent violence is of significant social importance.

One point that must be addressed here is our use of the terms "perpetrator" and "victim". Many academics and practitioners today do not like these terms, in part because they are too often used as identity terms. That is, they are commonly used as if having been victimized or having committed violence comprises the person's whole identity. Such uses of these terms are indeed problematic. However, in response-based practice, as set out by Coates and Wade (2007), these terms are used as interactional terms: in a specific interaction (or set of interactions) one person (the perpetrator) victimized another person (the victim). These experiences do not comprise the person's whole identity. Nor are they static: one person can be a perpetrator in one interaction and a victim in another. Therefore, the terms clearly describe the person's actions within the interaction. Moreover, the term "victim" rather than "survivor" is chosen because victim carries the connotation that a wrong was done to that person. We want to recognize the wrong done to the victim by accurately conveying the experience of victims. We understand accurate representation as a social justice and human rights practice.

\section{Beauty and The Beast}

The 1991 Walt Disney feature animation, Beauty and the Beast, is a children's film described on Wikipedia as "an animated musical romantic fantasy" ("Beauty and the Beast (1991 film)", 2015). The story draws on universally human themes of love and redemption. The prince in the story is cursed for his cruel behaviour and he must love and be loved in order to break the curse.

The appeal of Beauty and the Beast translated to sales. The film earned $\$ 608,435,483$ in worldwide box office sales and an additional $\$ 221,444,278$ in video sales in the United States alone ("Beauty and the Beast (1991)", 2018). It is considered to be one of Disney's most successful animated movies - both financially and socially. It has been hailed as a classic by critics and has been described as bringing together "traditional fairy tales and feminism" (Smoodin, 1993, p. 190). Nevertheless, it is not an unproblematically feminist tale. Instead, Beauty and the Beast reproduces many of the current societal problems in our social responses to male violence in intimate relationships. For example, it obscures and reformulates the violence to benefit the perpetrator.

Below, we present an analysis of some of the opening scenes of this animated movie to show how misrepresentation and social responses are used to accomplish the disappearing of violence and set viewers up to understand this tale as one of redemption and romance.

\section{Analysis: Misrepresentation and Social Responses}

In the film, the prince's physical appearance is changed to that of a beast when he is placed under a curse. In order to break the curse, he must love and be loved (which appears to mean he must share a kiss with a woman). There is also a deadline: he will remain a beast forever unless 
the curse is broken before the last petal falls from a magic rose. Some time after he is cursed, he imprisons a young woman, Belle. The rest of the film is about Belle and the Beast "falling in love".

The story begins with the narrator explaining how the prince came to have the outward appearance of a beast. Despite appearances, this past is not simply replayed in a neutral fashion, but is created by the words, sounds, and images the writers have chosen to describe the prince's deeds. The narrator's representation of this past event is the first social response to the Beast that viewers encounter within the film itself. It is offered to frame the story - it points viewers to certain events and away from others. For example, the narrator tells us that an enchantress came to the prince's castle disguised as an old beggar woman needing "shelter from the cold". In exchange for shelter, the woman offered the prince a rose. The prince, who is described as "spoiled, selfish, and unkind", "sneered at the gift and turned the old woman away". We are not told what he said nor given details of what he did. We are not told whether he ridiculed her, assaulted her dignity, or beat her. We are not told anything about who else was present or how they responded.

We are told that after the prince "turned her away", the old woman warned the prince "not to be deceived by appearances, for beauty is found within". She then revealed herself as a "beautiful enchantress"; after he saw that she was beautiful, the prince "apologized". But the enchantress cursed him so that his inner ugliness was visible to all. The enchantress' warning is not only the underlying moral of this story, it is also the first time we see misrepresentation and social response used together to create a false understanding. The narrator misrepresents the events: the prince is cast as acting immorally in part because he did not look past the physical appearances of the enchantress to see her hidden, inner beauty. Yet, in reality he behaved unjustly because in his position of ultimate privilege, he did not help a person in need. Had he helped the enchantress only because she was attractive, his actions would not have been moral. His immorality arose from his failure to help someone in need when that need was made apparent to him.

Despite the fact that it is a misrepresentation, the narrator's version of the enchantress' warning provides viewers with an orientation to the rest of the movie: they are to undertake to look past appearances. Incongruously, the Beast never has to learn to look past appearances to find inner beauty because Belle is described as physically beautiful. Belle, however, must not only look past the Beast's physical appearance but also his brutish and violent behaviour. These careful misrepresentations and characterizations are integrated with social responses to advance the narrative of the film.

Another incongruency in this opening narration is that power abuse is obfuscated. In the narration, the enchantress unjustly curses the castle servants. The servants are literally objectified by turning them into animated household objects. Female servants become a wardrobe, a tea pot, and a feather duster. Male servants become a mantle clock and a candelabra. But this injustice is never explained or focused upon. Trapping the servants in the castle and physically changing them into objects is simply glossed over: the enchantress "placed a powerful spell on the castle, and all 
who lived there". This abuse of presumably innocent people is never addressed. Nor are we told what will happen to them if the Beast does not break the curse before the time limit runs out. Minimizing the unjust cursing of the servants allows the filmmakers to engage in another form of misrepresentation: the obfuscation of motivation. The servants clearly have a personal stake in supporting the development of a romantic relationship between Belle and the Beast - when the Beast breaks the curse, the servants will also be set free. Yet, in the film, the servants appear to be motivated by fondness for the Beast and Belle rather than a desire to be free of the curse. We do not see the servants as pimp-like beings who are willing to sacrifice a young woman for their own self-gain. Instead, they come across as knowing friends or mentors of the Beast, who know the truth about the situation and the Beast himself.

In the scene below, misrepresentation and social responses continue to be used to advance the narrative and make the tale sensical to viewers. Belle has been imprisoned in the castle, and has been ordered by the Beast to attend dinner: "You will join me for dinner. That's not a request." Belle is in her "room" (which is still a "cell") with the Woman Wardrobe. The Woman Wardrobe pressures Belle to comply with the man who has unjustly imprisoned her, first by falsely representing the events and then by simply acting as if Belle will comply. Woman Wardrobe states: "Well now ... what shall we dress you in for dinner?" In this way, abduction, false imprisonment, and coercion are reformulated into mutual and pleasurable social interaction (see Coates, 1996; Coates, Todd, \& Wade, 2003; Coates \& Wade, 2007). One might be forced to eat in the presence of someone who has abducted, imprisoned, and abused her or him but this is not "sharing dinner".

Viewers are distracted from fully grasping the pressure the Woman Wardrobe is exerting on Belle by the insertion of a humorous scene where Woman Wardrobe delivers the double entendre, “Ooh ... let's see what I've got in my drawers!” Her words are accompanied by humorous actions that even young children could understand as humorous. Woman Wardrobe then picks out a pink dress and says, "You'll look ravishing in this one!", thereby bolstering the idea of mutual social interaction (e.g., "sharing dinner") and adding the notion of violent sexuality in a form all too accepted in Western cultures. According to the Oxford English Dictionary (2012), to ravish means to "seize and carry off (someone) by force" - this phrasing and depiction has been commonly used and supports the myth that women enjoy being raped (e.g., see Kuntz, 1995, or other critiques of Gone with the Wind). For example, Gone with the Wind depicts Scarlett O'Hara both being sexually assaulted by and falling in love with Rhett Butler (Kuntz, 1995). The reality of rape is rendered invisible by the many novels and films such as Gone with the Wind that romanticize and mystify it (Kuntz, 1995, p. 4007).

Belle responds to and resists Woman Wardrobe's pressure. She picks up the polite tone of Woman Wardrobe's talk and uses it: "That's very kind of you ...". Arguably, politeness is a very smart form of resistance by Belle. In situations of violence, being polite helps to remind people that there are limits on behaviour and obligations to other people - even when these norms have 
been broken. It would be unacceptable, in polite company, for example, to beat or rape Belle. In this way, Belle could be understood as resisting the Beast's violence by increasing her safety.

The mutualization (see Coates \& Wade, 2007) of the ongoing social interaction as "going to dinner" that was first used by the Beast, and then picked up and used by Woman Wardrobe, is also picked up by Belle. She not only uses the term "dinner" but also uses the mutualization to pretend that she has been issued an invitation that she could refuse without potentially dangerous consequences. She politely tells Woman Wardrobe that she is going to "decline" the false invitation: "That's very kind of you ... but I'm not going to dinner." For a moment, the pretense is up and Woman Wardrobe gasps, "But you must!". Before the audience can critically attend to this scene, it is broken up by Cogsworth (the man who looks like a mantel clock) coming in and dispelling the moment of clarity by furthering the false, mutualizing representation. With formal politeness, he announces, "Ahem, ahem, ahem, ahem. Dinner ... is served."

In the next scene, we see both Cogsworth's and the Beast's responses to Belle's resistance. Cogsworth is hesitant, unsure how to tell the Beast that Belle has refused the pretense. He begins with politeness: "Uh ... good evening." The Beast immediately begins to look angry. And he demands impatiently: "Well ... where is she?" Cogsworth stutters and then finally states that Belle is not coming:

Who? Oh! (Nervous laughter) The girl. Yes ... uh ... well, actually, she's in the process of ... uh ... circumstances being what they are ... [hesitantly] She's not coming.

Cogsworth's response to the Beast reveals that he fears the Beast. He is dysfluent, struggling to find a way to tell the Beast that Belle is not coming. When he does answer, he protects himself (as the messenger) and Belle (as the victim) by: (a) misrepresenting the Beast's actions as "circumstances" rather than deliberate action; and (b) saying, "She's not coming", a phrasing that downplays Belle's agentive resistance as opposed to saying, "She has refused to come." By downplaying Belle's agency, Cogsworth arguably increases her safety. That Cogsworth was right to fear the Beast is clear when the Beast responds by roaring, "WHAT?!" and angrily charging upstairs to confront and further threaten Belle.

If these scenes had been placed in the movie sequentially as we have just described them, the pretense of mutuality would have been harder to create. The intervening scene, described below, focuses on the servant's responses to the Beast and his responses to the social responders (his servants). This scene shows the Beast as behaving non-violently, listening to, and trying to do what his servants are telling him to do. The scene opens with the Beast pacing back and forth in front of the fire asking himself why Belle has not come down. He then turns to Lumiere (the candlestick) and Mrs. Potts (the teapot) and asks impatiently, "Why isn't she here yet?"

Both servants use misrepresentation as they plead with the Beast to behave better. Mrs. Potts alludes to Belle's false imprisonment but omits mentioning that the Beast is the agent of that 
violence: "Oh, try to be patient, sir. The girl has lost her father and her freedom all in one day." Lumiere highlights a more self-serving motivation for the Beast to show patience: "Uh, master? Have you thought that perhaps this girl could be the one to break the spell?" The Beast responds, “Of course I have! I'm not a fool." Lumiere injects humour by excitedly and romantically saying, "Good! So ... you fall in love with her, she falls in love with you, and — poof! — the spell is broken. We'll be human again by midnight!" while acting it out. While this scene conveys that the servants are highly motivated to connect Belle and the Beast by any means necessary to break the curse, the "romantic" humour works to diminish the servants self-interest. Lumiere stresses the urgency of the connection by saying, "The rose has already begun to wilt".

The Beast is then depicted as forlorn when he says, "It's no use. She's so beautiful, and I'm ... well, look at me!" Here, the Beast is focused on as a victim who should be pitied rather than a perpetrator. In response to the Beast's apparent misery, Lumiere and Mrs. Potts rush in with advice:

MRS. POTTS: Oh, you must help her to see past all that.

BEAST: I don't know how.

MRS. POTTS: Well, you can start my making yourself more presentable. Straighten up, try to act like a gentleman.

[Beast sits up straight and looks more gentlemanly.]

LUMIERE: Ah, yes, yes, when she comes in give her a dashing, debonair smile. Come, come, show me the smile. [Beast moves his mouth in an awkward-scary looking smile — as if he does not know how to smile.]

MRS. POTTS: But don't frighten the poor girl.

[Beast shakes his head.]

LUMIERE: Impress her with your rapier wit.

[Beast nods.]

MRS. POTTS: But be gentle.

LUMIERE: Shower her with compliments.

MRS. POTTS: But be sincere.

LUMIERE: And above all ...

BOTH: You must control your temper! 
International Journal of Child, Youth and Family Studies (2019) 10(1): 119-136

[The door creaks and opens. Beast looks at the door expectantly.]

LUMIERE: Here she is!

But it is not Belle who comes in but Cogsworth. By the end of this scene, the writers have begun transforming the Beast from threatening and frightening to romantic and enchanting. They do this by evoking from us a sympathetic response to the Beast because we see him worrying about how he looks. Also, when he is spoken to quite bluntly by the servants (e.g., when they instruct him to make himself presentable, be a gentleman, smile, impress her with wit, be gentle, compliment her, and be sincere), the Beast responds well. He listens to these instructions rather than asserting his power. In this way, the Beast's violent behaviour gets reformulated to merely uncouth or unknowing behaviour. He lacks refinement because he does not know how to be well mannered. But he is willing to learn (as he demonstrates by doing what his servants instructed). This scene functions to depict the Beast as a kind of diamond in the rough, who only needs polishing to be something or someone spectacular. The offered characterization of the Beast is dependent upon the Beast's violent behaviour being minimized and reformulated into actions consistent with being uncouth. For example, in this scene we see his violence characterized by the servants as "temper".

The film relies on and reproduces several myths about men who use violence against intimate partners: namely, that they do not engage in deliberate acts of violence, that they do not mean to hurt their partners (so it is not really violence), and that they are not truly violent men because they are not violent all the time. In fact, men who use violence do so deliberately - not out of ignorance or lack of knowing (see Coates \& Wade, 2007). Except perhaps in rare cases, men who use violence also know how to be respectful and kind. Given the deliberateness of intimate partner violence and that these men have social competencies, it is not surprising that in real life, men who use violence are not violent all the time. Instead, their use of violence tends to be a strategy for exerting coercive control over intimate partners. In the next scene, we see the Beast use deliberate violence in an attempt to coercively control Belle.

Because this film is about redemption, it also includes moments where if you look, you clearly see the Beast's violence. For example, when Belle uses the Beast's mutualization to resist his violence by not going down for the "dinner", the Beast responds with anger. The servants run after him, but they do not do anything to stop him, as you would expect if he were truly dangerous. But even, within these scenes, the Beast's abusive and violent actions are misrepresented. As the Beast runs up the stairs, the servants follow him and plead with him:

COGSWORTH: Your Grace! Your Eminence! Let's not be hasty!

[Beast ignores him and bangs forcefully on Belle's door and growls at her.]

BEAST: I thought I told you to come down for dinner! 
International Journal of Child, Youth and Family Studies (2019) 10(1): 119-136

[The servants look at each other and shake their heads.]

BELLE: [through the door and in a defiant tone] I'm not hungry.

BEAST: [in a loud and threatening tone] You'll come out or I'll ... I'll ... I'll break down the door!

Thus, we see that the Beast is continuing to use violence and the threat of violence against Belle and that that violence is misrepresented (e.g., "Let's not be hasty" versus "Beast, do not threaten or hurt Belle"). The servants respond to his threats against Belle by pleading with the Beast:

LUMIERE: Master ... I could be wrong, but that may not be the best way to win the girl's affections.

COGSWORTH: [pleadingly] Please ... attempt to be a gentleman.

[Beast responds by blaming Belle, not himself and his violent behaviour.]

BEAST: [in a menacing tone] But she is being so difficult!

[Mrs. Potts encourages the Beast to change his tone and he does, somewhat.]

MRS. POTTS: Gently ... gently.

BEAST: [in a petulant tone] Will you come down to dinner?

BELLE: No!

The Beast then points to the door while looking at the servants as if to say, "You see, it is her fault." In this way, he continues to blame Belle and not himself. The servants respond by continuing to try to influence the Beast's behaviour:

COGSWORTH: Ah, ah, ah ... suave. Genteel.

BEAST: [bowing at the door; in a formal voice] It would give me great pleasure if you would join me for dinner.

COGSWORTH: [softly and quickly] Ahem, ahem, we say "please”.

BEAST: Please.

[Belle resists, still using politeness and the safety it offers.]

BELLE: No, thank you!

BEAST: [furiously] You can't stay in there for ever! 
International Journal of Child, Youth and Family Studies (2019) 10(1): 119-136

\section{BELLE: Yes I can!}

BEAST: Fine! Then go ahead and STARVE!!

When he does not get what he wants, the Beast threatens Belle directly with starvation and instructs the servants to withhold food from her:

BEAST: [to servants] If she doesn't eat with me, then she doesn't eat at all.

[Beast growls and runs back down the hall, slamming a door and causing a piece of the ceiling to fall on Lumiere.]

MRS. POTTS: Oh dear. That didn't go very well at all, did it?

From this scene, we are taken to another where the Beast is shown in a room by himself. He talks to himself, not about his own violent behaviour but about the unreasonableness of Belle's resistance:

BEAST: I ask nicely, but she refuses! What a - what does she want me to do beg?

He then further abuses Belle by violating her privacy and surveilling her. He picks up a magic mirror and says, "Show me the girl." The mirror shows Belle in her room, clearly upset, and talking with Woman Wardrobe who is actively trying to advance the agenda of breaking the curse:

WOMAN WARDROBE: [to Belle] The master's really not so bad once you get to know him ... why don't you give him a chance?

BELLE: [upset] I don't want to get to know him! I don't want to have anything to do with him!

Throughout the film, the servants continue to exert pressure on Belle to connect with the Beast. This scene ends with the Beast being depicted as pitiful rather than violent. He ends his surveillance of Belle and then says softly and sadly, 'I'm just fooling myself. She'll never see me as anything ... but a monster." After he says this, a rose petal falls to show viewers that he is running out of time to break the curse. He then says, "It's hopeless." He puts his head in his paws and looks despondent.

The story comes across as romantic and humorous. It ends with a kiss and the breaking of the curse. Its success in misrepresenting and reformulating the Beast's violence is not limited to the movie itself, but is clear in the social responses of viewers and writers of online plot summaries. In the words of one website:

Belle is a bright and beautiful young woman who's taken prisoner by a hideous beast in his castle. Despite her precarious situation, Belle befriends the castle's 
International Journal of Child, Youth and Family Studies (2019) 10(1): 119-136

enchanted staff — a teapot, a candelabra and a mantel clock, among others — and ultimately learns to see beneath the Beast's exterior to discover the heart and soul of a prince. ("Beauty and the beast (1991)", 2018)

Here, the summary begins with an accurate description: the Beast took Belle "prisoner" in his castle. But, the seriousness of this situation begins to be downplayed. The summary describes Belle's situation not as "dangerous", "grave", or "grievous", but as "precarious", which connotes risk but also uncertainty. It is uncertainty, not danger, that is carried forward in the summary and Belle is described as "[learning] to see beneath the Beast's exterior to discover the heart and soul of a prince". Thus, as written, it is Belle's perception that needed to change, not the Beast's abusive and violent behaviour.

Movie theater sites post a summary by Tribune Media Service (2018) that describes the prince as merely "arrogant", not violent or abusive. It falsely represents the Beast as being in "isolation" and credits Belle for "[drawing] out the cold-hearted Beast". This description disappears the Beast's violence and arguably misrepresents Belle actions as drawing out the Beast rather than resisting his violence.

\section{Conclusion}

We have not presented an exhaustive analysis of this film; instead, we have focused on misrepresentation and social responses in the foundational, early scenes of the movie. These scenes prepare viewers to accept that the Beast could fall in love with Belle and she with him. We showed how violence, abuse, and self-serving motives in the film are talked away; that is, they are misrepresented and reformulated. The Beast's abusive, threatening, and violent actions are minimized (e.g., "temper", "hasty”), distanced or completely severed from his agency (e.g., Belle "lost her father and her freedom", "Let's not be hasty"), and obfuscated (e.g., "circumstances"). Misrepresenting the self-serving motivations of the Beast and his servants for breaking the curse on all of them is key to also successfully misrepresenting the Beast's violence. It is through the servants, rather than directly from the Beast himself, that much of the misrepresentation and reformulation is accomplished. The servants befriend Belle and use their friendships with her to exert pressure on Belle to go along with the Beast's demands for the appearance of a courtship. They misrepresent the situation and the Beast's actions in ways that further their agenda of having the curse broken. In the guise of friendship and support, they put pressure on Belle to go along with their agenda. The self-gain underlying both the Beast's and the servants' actions are never addressed. Instead, the Beast is depicted as earnestly engaging in romance and the servants as earnestly supporting and helping a romance. In this way, Beauty and the Beast is a means of socialization. Ideas about how men and women should behave and the meaning of those actions in romantic or intimate relationships are conveyed. Thus, each misrepresentation and each social response is like a strand in a spider web, each joining with the others to ensnare Belle and unsuspecting viewers in a fairy tale about romance and redemption. 
International Journal of Child, Youth and Family Studies (2019) 10(1): 119-136

The misrepresentation and social responses in Beauty and the Beast are foundational to having the tale make sense to viewers. Through these processes, the filmmakers change the meaning of the events so that viewers can accept that a man who imprisons, abuses, and threatens a woman could actually not mean any of those actions; that is, they are not deliberate acts of violence but acts of ignorance and even positive intention. We can make sense of the Beast falling in love with Belle, and even more importantly we can make sense of Belle falling in love with the Beast. Like the filmmakers, we once again ask our readers to look beyond - this time to hold the harsh realities of violence as central to the meaning-making process and to look past the countless myths that minimize, romanticize, and mutualize male violence against women in intimate relationships.

The real-life lessons to be learned are not those sold by Disney. Surveys show us that some men and boys beat and rape women and girls they date. In real life it is not the women's and girls' actions that cause the men and boys to beat, rape, or otherwise abuse them. In real life, there is not such a neat binary of opposites, no marriage of complementary characteristics. In real life, those who choose to use violence do not undergo a metamorphosis caused by women and girls' resistance to their violence. If this were the case, then all people who use violence would be transformed the very first time they abused or violated someone else. And in real life the abusive person is very unlikely to turn into a kind prince.

These sobering realities of violence must be taken into account in any depictions, developmental theories, and other social responses. To do otherwise is to risk completely misunderstanding people. Theories or assessments that do not take into account the person's full context are biased — what we call the "benign-world-bias" (Coates \& Wade, 2012). The benignworld-bias is the false assumption that the person lives in a world where people are kind, considerate, and helpful, or at the very least neutral. The consequences of adopting this bias, which most theories of human development do, would be something akin to the socially constructed cultural biases in theories and assessments. Where violence has occurred, the negative consequences of adopting the benign-world-bias may be even more problematic than adopting a cultural bias. When one adopts the benign-world-bias, one denies the extreme nature of violence, obfuscates the social and material ensuing circumstances, and ignores the social responses to victims and perpetrators. The social response of ghetto-izing violence is profoundly negative and has resulted in great distortions of people (including their lives, characters, and actions) and the violence itself.

As parents, professionals, and community members, we need to understand ourselves as influential social responders to victims and perpetrators of violence. Far too often, we use language that minimizes teen violence and abuse, largely due to an adopted dominant discourse and the sociopolitical structures that are in place. For example, we call harassment and assault "bullying", which minimizes the degree of violence and abuse as well as the harm done to the victim. There is widespread, accepted language for sexualized assault, such as "date-rape", which presents the motive of rape as somehow connected to romance and possibly some degree of consent — as if it 
was a simple misunderstanding rather than a calculated attack. Our culture frequently mutualizes beatings as "conflict" which presents the victim as having a role in the conflict and being responsible for the conflict (and the corresponding solution). Adult, adolescent, and child perpetrators of violence are often excused and victims blamed. For example, people will dismiss abuse and violence as "kids will be kids". Even judges have minimized sexualized assaults against girls by saying that "boys will be boys", as if sexualized assault and rape of girls is a natural consequence of being a boy (Coates, 1996). In schools, teachers and administrators have mutualized violence and suspended victims from school along with the perpetrators - ironically, on the grounds of "zero tolerance for violence" policies (for a description of these policies, see National Association of School Psychologists, 2001). In our homes and communities, we negatively label people who seek safer people and places as "needy" or "dramatic" (Charuvastra \& Cloitre, 2008; Moore, 2014; Ullman, 2010). These responses, even when done with the best of intentions, are not helpful and can be very harmful to victims.

As described in the analysis, the 1991 Disney film Beauty and the Beast reproduces versions of many myths about men's and boy's violence against women and girls in intimate relationships. It also connects to flawed academic theories and constructs. For example, in depicting Belle and the Beast as a binary of opposites, the story maps on to the flawed but widely used cycle theory of violence (Walker, 1980, 2009). In Walker's terms, Beauty and the Beast could be seen as having complementary characteristics that held them together. In this film, however, Belle acts outside of the imputed complementary characteristics by overtly resisting the Beast's orders. Belle acts as if he will not hurt her, kill her, rape her, or retaliate with any other forms of violence or abuse when she refuses his orders and demands. In doing so, Belle does not act in ways that preserve the imputed complementary characteristics between abuser and abused and so the binary is broken and the Beast is saved.

Another flawed concept that this fairy tale maps onto is "Stockholm syndrome", which is a psychological construction invented by Swedish criminologist and psychiatrist Nils Bejerot (1974). Bejerot invented this concept to explain why hostage Kristin Enmark was critical of the police and other officials (including Bejerot) who handled this six day hostage crisis in Sweden. This concept has been picked up and used uncritically around the world to claim that people, perhaps especially women, become emotionally aligned with their captors. Such claims rely on decontextualized descriptions of what actually happened. They do not take into account perpetrator actions, victim resistance, and the role of social responses. We have critiqued this flawed construct in various presentations (see Wade, 2015).

In this article, we have shown how misrepresentation and social responses are used to disappear the Beast's violence against Belle and advance the narrative of a fairy-tale love story. The Beast is depicted as an uncouth man who can be taught manners rather than a violent man who can choose to stop being violent. Belle becomes a young woman who learns to see through appearances to find inner beauty rather than a victim of violence who must play along to gain some 
International Journal of Child, Youth and Family Studies (2019) 10(1): 119-136

measure of safety in a dangerous situation. This tale represents a large and troubling social problem of people misrepresenting perpetrator actions, victim resistance, and the violence itself. 
International Journal of Child, Youth and Family Studies (2019) 10(1): 119-136

\section{References}

Beauty and the beast (1991). (2018, September 10). Retrieved from https://www.thenumbers.com/movie/Beauty-and-the-Beast-(1991)\#more

Beauty and the beast (1991 film). (2015). Retrieved from https://en.wikipedia.org/wiki/Beauty_and_the_Beast_(1991_film)

Bejerot, N. (1974). The six day war in Stockholm. New Scientist, 61, 486-487.

Centers for Disease Control and Prevention. Sexual violence. Retrieved from https://www.cdc.gov/violenceprevention/sexualviolence/

Charuvastra, A., \& Cloitre, M. (2008). Social bonds and posttraumatic stress disorder. Annual Reviews of Psychology, 59, 301-328. doi:10.1146/annurev.psych.58.110405.085650

Coates, L. (1996). Discourse analysis of sexual assault trial judgments: Causal attributions and sentencing (Unpublished doctoral dissertation). University of Victoria, British Columbia, Canada.

Coates, L. (1997). Casual attributions in sexual assault trial judgements. Journal of Language and Social Psychology, 16(3), 278-296.

Coates, L., Todd, N., \& Wade, A. (2003). Shifting terms: An interactional and discursive view of violence and resistance. Canadian Review of Social Policy, 52, 116-122.

Coates, L., \& Wade, A. (2004). Telling it like it isn't: Obscuring perpetrator responsibility for violent crime. Discourse and Society, 15(5), 499-526. doi:10.1177/0957926504045031

Coates, L., \& Wade, A. (2007). Language and violence: Analysis of four discursive operations. Journal of Family Violence, 22(7), 511-522. doi:10.1007/s10896-007-9082-2

Coates, L., \& Wade, A. (2012). Tell it like it is: How professionals misrepresent sexualised violence against children. Context, June, 20-24.

de Certeau, M. (1984). The practice of everday life (S. Rendall, Trans.). Berkeley, CA: University of California Press.

DeKeseredy, W., \& Kelly, K. (1993). The incidence and prevalence of woman abuse in Canadian university and college dating relationships. Canadian Journal of Sociology, 18(2), 137-159. doi:10.2307/3341255

Fowler, R., Hodge, B., Kress, G., \& Trew, T. (1979). Language and control. London, UK: Routledge. 
International Journal of Child, Youth and Family Studies (2019) 10(1): 119-136

Kelly, K. D. (2006). Violence in dating relationships [Overview paper]. Ottawa, ON: Public Health Agency of Canada. Retrieved from https://www.canada.ca/en/publichealth/services/health-promotion/stop-family-violence/prevention-resourcecentre/women/violence-dating-relationships.html

Kuntz, T. (1995, February 19). Word for word. A scholarly debate; Rhett and Scarlett: Rough sex or rape? Feminists give a damn. The New York Times. Retrieved from https://www.nytimes.com/1995/02/19/weekinreview/word-for-worda-scholarly-debaterhett-scarlett-rough-sex-rape-feminists-give.html

Moore, S. (2014, October 22). Reeva Steenkamp was a victim of male violence. That is the real story. The Guardian. Retrieved from http://www.theguardian.com/commentisfree/2014/oct/22/discussion-of-reeva-steenkampkilling-has-sidelined-male-violence

National Association of School Psychologists. (2001). Zero tolerance and alternative strategies: A fact sheet for educators and policy makers. Retrieved from https://www.justice4all.org/wp-content/uploads/2016/04/Zero-Tolerance-and-AlternativeStrategies-NASP-Fact-Sheet.pdf

Oxford English Dictionary. (2012). Ravish. Oxford, England: Oxford University Press.

Perreault, S. (2015). Criminal victimization in Canada, 2014 [Statistics Canada Catalogue no. 85-002-X]. Juristat, 35(1), 1-43. Retrieved from https://www150.statcan.gc.ca/n1/en/pub/85-002-x/2015001/article/14241eng.pdf?st=edMLsraJ

Prince (2001)

Richardson, C. (2008). A word is worth a thousand pictures: Working with Aboriginal women who have experienced violence. In Lynda R. Ross (Ed.), Feminist counselling: Theories, issues and practice (pp. 122-148). Toronto, ON: Women's Press.

Richardson, C., \& Bonnah, S. (2015). Taking children's resistance seriously. In S. Strega \& J. Carrière (Eds.), Walking this path together: Anti-racist and anti-oppressive child welfare practice (2nd ed., pp. 193-216). Winnipeg, MB: Fernwood.

Richardson, C., \& Wade, A. (2008). Taking resistance seriously: A response-based approach to social work in cases of violence against Indigenous women. In S. Strega \& J. Carriere (Eds.), Walking this path together: Anti-racist and anti-oppressive child welfare practice. Winnipeg, MB: Fernwood.

Smoodin, E. (1993). Animating culture: Hollywood cartoons from the sound era. New Brunswick, NJ: Rutgers University. 
International Journal of Child, Youth and Family Studies (2019) 10(1): 119-136

Tribune Media Service. (2018). Event calendar: Beauty and the Beast. https://www.dohafilminstitute.com/films/beauty-and-the-beast

Turpel-Lafond, M. E. (2012). Trauma, turmoil and tragedy: Understanding the needs of children and youth at risk of suicide and self-harm [Report]. Victoria, BC: Representative for Children and Youth. Retrieved from https://rcybc.ca/sites/default/files/documents/pdf/reports_publications/trauma_turmoil_trage dy.pdf

Ullman, S. (2010). Talking about sexual assault: Society's response to survivors. New York, NY: American Psychological Association.

Wade, A. (2015, May). The myth of Stockholm syndrome. Paper presented at the Mind the Gap Conference, Cowichan Bay, BC, Canada.

Walker, L. (1980). The battered woman. London, UK: Harper Collins.

Walker, L. (2009). The battered woman syndrome. New York, NY: Springer.

World Health Organization. (2017). Violence against women. Retrieved from: https://www.who.int/news-room/fact-sheets/detail/violence-against-women 